\title{
PEREGRINE FALCON IN MANITOBA - AN HISTORICAL PERSPECTIVE
}

ROBERT P. BERGER and ROBERT W. NERO, Manitoba Wildlife Branch, Box 14, 1495 St. James Street, Winnipeg, Manitoba. R3H OW9

Winnipeg has attracted attention recently because a pair of Peregrine Falcons nested for three consecutive years on the Delta Winnipeg Hotel as a result of U.S. and Canadian reintroduction efforts. This paper, however, deals exclusively with historic occurrences predating the Peregrine Falcon recovery project in Manitoba.

Since the earliest recorded sightings, the "Duck Hawk" or Peregrine Falcon in Manitoba is referred to as either a transient, occasional winter visitant or occasional summer resident. Although definite breeding records were lacking, it probably bred sparingly as it was recorded in summer. ${ }^{4}$ The present note records some breeding for the period prior to 1981.

Northern Manitoba As early as 1880, Bell recorded a male peregrine, and Macoun listed two specimens obtained from York Factory (Figure 1). ${ }^{9}$ Taverner and Sutton called the peregrine at Churchill "a fairly common transient and summer resident; probably nests in suitable localities." Although they did not find evidence of breeding, birds were seen and collected between 27 May and 11 June, and an adult male was regularly observed during the last week of June and the first two weeks of July in the Churchill area. ${ }^{11}$
Jehl and Smith stated that although few records exist for the Churchill area, migrant peregrines usually arrive from 6 to 18 May and depart between mid-August and midSeptember. "The virtual absence of summer records in recent years indicates that peregrines no longer breed in the Churchill area. Perhaps they nested as late as 1957, when Mrs. Beckett observed a pair courting near Cape Merry." In Bechard's review of historic nesting records, he states that only presumptive evidence exists that peregrines once occupied suitable sites along the Hudson Bay near Churchill. ${ }^{1}$

A Peregrine Falcon nesting habitat evaluation was conducted for northern Manitoba in $1990 .^{2}$ Although no peregrines were observed, 33 potential nesting cliffs were recorded over the $3,438 \mathrm{~km}$ route.

Central Manitoba Shortt and Waller reported that the Peregrine Falcon was not common, but was well known to the Indians of Lake St. Martin who claimed to have found its nest on the limestone ridge at the north end of the lake. ${ }^{10}$

In "Chickadee Notes" (1948, No. 1400), Lawrence described peregrines nesting near Grand Rapids, and near Minaki, Ontario. Valentine McKay indicated strong understand- 


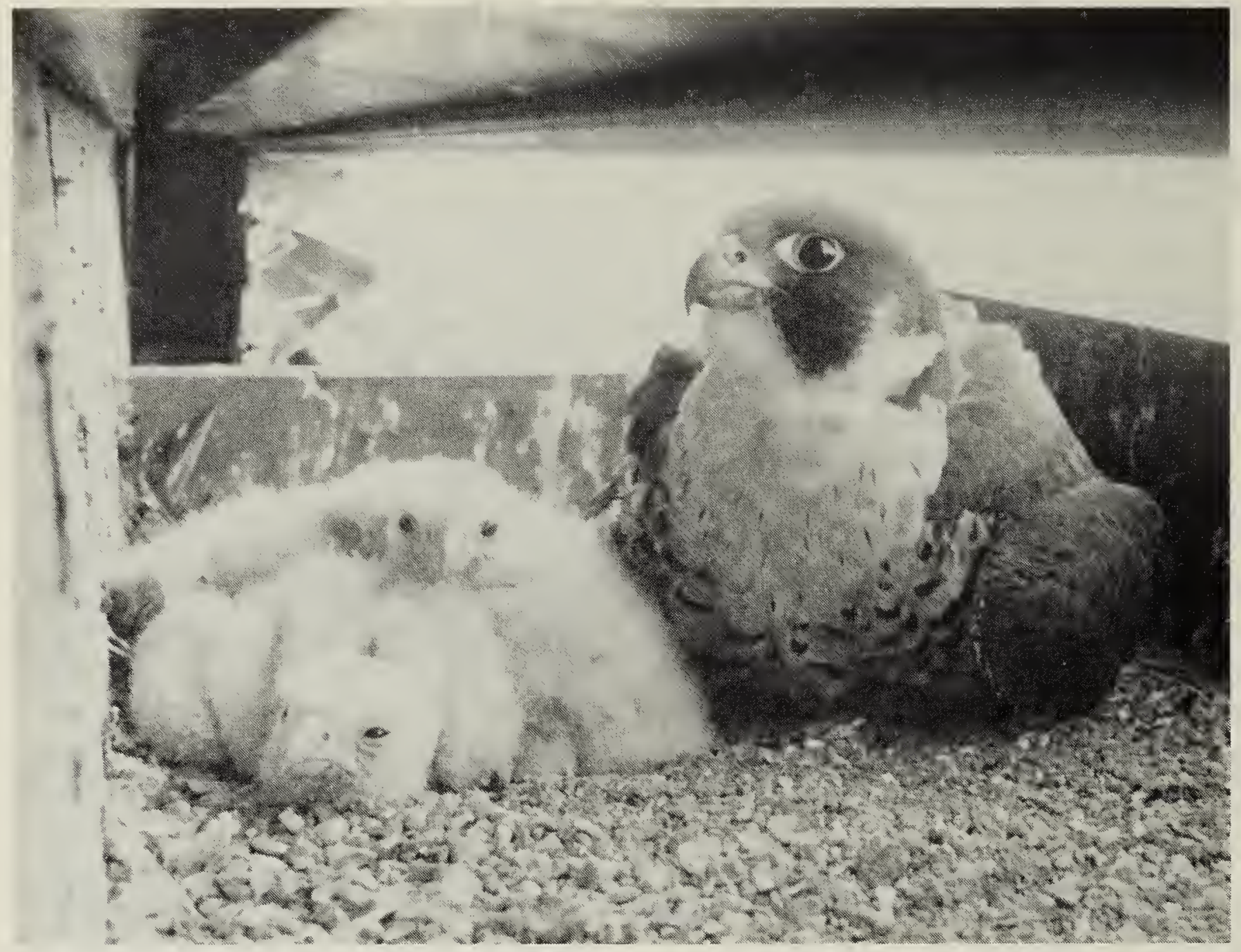

Peregrine nesting on Delta Winnipeg Hotel, 1989

Robert $P$. Taylor

ing of the Peregrine Falcon's hunting habits and nesting behaviour. He goes on to describe several locations. "Owing to the Duck Hawk's habit of always nesting on an inaccessible ledge of a perpendicular cliff, it is hard for one to look into the nest to examine the contents. These hawks nest every summer on the limestone cliffs of Pony Island, near Selkirk Island, Lake Winnipeg and also just above the Demichage Rapids, where there is a high bluff called Anchor Point. Last summer [1947] I saw a nest on a ledge of a perpendicular limestone cliff near the Gill River on Lake Winnipeg. Both hawks were greatly excited and antagonistic to our presence and swooped down on us several times in a curve directly below the cliff. I presume that anyone trying to invade their nesting site would meet with violent opposition." ${ }^{, 8}$ (There were 35 other records in "Chickadee Notes." Table 1)
Western Manitoba There were several reports of migrating peregrines in the late $1800 \mathrm{~s}$, and migration records were listed for Portage la Prairie, Carberry and Two Rivers. One Peregrine Falcon was collected in its first plumage on 26 July 1884 near Carberry. ${ }^{13}$

O.G. Turner, Jr. collected two Peregrine Falcon eggs on 20 May 1887 , from a nest $13.3 \mathrm{~m}$ above ground on the ledge of a small cliff near Gladstone, Manitoba. These eggs are in the museum collection of the Western Foundation of Vertebrate Zoology, California. Egg size could not be used for identification since eggs of Peregrine Falcons are similar to those of Prairie Falcons. However, Bechard reported that the dark red colour of the eggs was typical of Peregrine Falcons so he judged the identification to be valid. ${ }^{1.6}$ It can be argued that a $13.3 \mathrm{~m}$ cliff near Gladstone, especially downstream along 
the White Mud River, is not feasible. However, $20 \mathrm{~km}$ west and northwest of Gladstone, the topography is certainly rugged enough, supporting steep elevation changes of greater than $15 \mathrm{~m}$ along the course of creeks and other sites. The eggs were likely collected in this area.

Hochbaum called the peregrine an uncommon spring and fall migrant in the Delta Marsh region of Manitoba. ${ }^{5}$

Eastern Manitoba In the Pinawa-Lac du Bonnet area, Taylor classified the peregrine as a rare transient and occasional winter visitant. He suggested that it was unlikely peregrines had ever bred here as limited historical records of sightings occurred only during migration (i.e., 20 April-13 May; 31 August-1 October). ${ }^{12}$

A.G. Lawrence however, observed potential nesting locations in nearby Ontario and at least one active nest ("Chickadee Notes," No. 1400). "On the prairies, the Duck Hawk is noted usually in spring and fall following the migrating flocks of ducks and shorebirds, but we have found it in summer dwelling amongst the rocky headlands of the Lake of the Woods and Winnipeg River, and have seen a brood just out of the nest (first reported by W. Adams, Winnipeg) on Thompson's island, near Minaki, Ontario," $33 \mathrm{~km}$ east of the ManitobaOntario border. ${ }^{8}$

Southern Manitoba Hine called the peregrine a "tolerably common summer resident" in the Winnipeg area. $^{13}$

Lawrence ("Chickadee Notes," No. 497) mentions an immature peregrine being captured while asleep on a window sill of the Winnipeg Hydro warehouse on Arlington Street by $P$.
Stewart in September, 1930 (Table 1). It was photographed, banded and released. The photo appears in his column. $^{8}$

In "Chickadee Notes" No. 1569, Lawrence wrote about an outing by the Manitoba Museum Association and the Natural History Society during the second week of June 1951, in which apparently a pair of peregrines was seen in the Stony Mountain area. They observed one peregrine kill and carry away a shorebird. "It was probably a female Duck Hawk as a male was seen over the slough in the afternoon.".8

According to L.T. Simmons, a pair of peregrines nested on a ledge near the top of the King Edward Municipal Hospital on Churchill Drive overlooking the Red River about 1960. The late Jack Mclntyre, then administrator of the hospital, told Simmons about the nesting at a time when the birds were still present. He swore Simmons to secrecy in the belief that otherwise the birds would be disturbed. Simmons said he saw two downy chicks resting on the bare bricks of the ledge which was at the southeast corner of the building overlooking a vegetable garden. Simmons said he saw pieces of pigeon remains scattered on the nest ledge, especially sections of the forewing. The ledge was "messy" so that the chicks were not altogether resting on bare brick. Simmons saw the nest ledge with the two young on two separate occasions, with the chicks in both downy and advanced states (R.W. Nero, pers. comm., 1989).

Simmons also said that a single peregrine took up residence for some time at the Legislative Building in the 1930s, roosting daily on the ledge at the base of the Golden Boy. Grant Churcher, who ran the 
Table 1: PEREGRINE RECORDS IN MANITOBA 1921-55

IN "CHICKADEE NOTES" BY A.G. LAWRENCE

\begin{tabular}{|c|c|c|c|}
\hline $\begin{array}{l}\text { Column } \\
\text { Number }\end{array}$ & Location & $\begin{array}{l}\text { Date } \\
d / m / y\end{array}$ & Observer \\
\hline 10 & Gimli & 23 May 1921 & C.G. Harold \\
\hline 33 & Aweme & 28 Sep 1921 & N. Criddle \\
\hline 113 & Oak Lake & 14 May 1923 & H. Battersby \\
\hline 163 & Whitewater Lake & 30 Apr 1924 & C.G. Harold \\
\hline 217 & Oak Lake & 16 May 1925 & H. Battersby \\
\hline 268 & Oak Lake & 04 May 1926 & H. Battersby \\
\hline 317 & Portage la Prairie & 17 Apr 1927 & James Cowan \\
\hline 318 & Oak Lake & 17 Apr 1927 & H. Battersby \\
\hline 319 & Treesbank & 26 Apr 1927 & N. Criddle \\
\hline 369 & Hillside Beach & 05 Apr 1928 & F.J. Rogers \\
\hline 371 & St. Vital, Winnipeg & 20 Apr 1928 & H. Mossop \\
\hline$\hat{S} 72$ & Oak Lake & 10 May 1928 & H. Battersby \\
\hline 378 & Winnipeg & 24 May 1928 & L.T.S. Norris \\
\hline 425 & St. Vital, Winnipeg & 11 May 1929 & H. Mossop \\
\hline 427 & Oak Lake & 16 May 1929 & H. Battersby \\
\hline 479 & Delta & 24 May 1930 & C.L. Broley \\
\hline 497 & Winnipeg & 24 Sep 1930 & P. Stewart \\
\hline 577 & Winnipeg area & 10 Apr 1932 & R.M. Watt \\
\hline 578 & Hillside Beach & 09 Apr 1932 & F.J. Rogers \\
\hline 631 & St. Francois Xavier & 17 Apr 1933 & C.L. Broley \\
\hline 683 & Whitemouth & 22 Apr 1934 & V. Latta \\
\hline 688 & East Bay & 24 May 1934 & E. Robinson \\
\hline 719 & Virden & 23 Dec 1935 & J. Pritchard \\
\hline 739 & Hillside Beach & 18 May 1935 & F.J. Rogers \\
\hline 786 & City Park, Winnipeg & $29 \operatorname{Mar} 1936$ & R. Tidmus \\
\hline 844 & Whitemouth & 12 May 1937 & V. Latta \\
\hline 1052 & East Bay & 19 May 1941 & E. Robinson \\
\hline 1207 & Delta & 30 Apr 1944 & H.A. Hochbaum \\
\hline 1250 & Rosenfeld & ? Sep 1944 & T. Wallis \\
\hline 1254 & Lac du Bonnet & 30 Apr 1945 & A.G. Lawrence \\
\hline 1569 & Stony Mountain & ? Jun 1951 & Nat. His. Society \\
\hline 1616 & Haywood & 01 May 1952 & H. Mossop \\
\hline 1666 & Marquette & 03 Apr 1953 & H. Mossop \\
\hline 1717 & Legislature, Wpg. & 08 Apr 1954 & G. Parfitt \\
\hline 1724 & Churchill & 18 May 1954 & E. Beckett \\
\hline
\end{tabular}

government greenhouse, Ralph Fryer and Angus Shortt also knew about this falcon (R.W. Nero, pers. comm., 1989).

Gardner called the peregrine a rare transient in the Oak Hammock Marsh region. He has recorded 38 sightings since 1953, dating from 30 April to 30 May, and from 13 August to 30 September. $^{3}$ Summer records do not exist for peregrines in the area after 1953, but the Stony Moun- tain pair was probably observed at Oak Hammock in 1951, because the naturalists mention a slough, and St. Andrew's Bog was the most prominent one in the area.

Discussion Although the data are limited, the available evidence suggests that at the time of initial settlement up until the early 1950s, the Peregrine Falcon was a rare breeding resident of Manitoba. 
Lawrence's record of peregrines nesting in the Grand Rapids area seems plausible. Pony Island, Demichage Rapids and the Gill River areas are suitable nesting locations, and to this day have not been closely examined for nesting peregrines. The pair nesting on the King Edward Municipal Hospital in the 1960s also appear valid. Finally, the egg set collected from the Gladstone area provides the first positive evidence of nesting of peregrines in Manitoba prior to 1989. The Thompson's Island fledglings seen by A.G. Lawrence near Minaki, Ontario, just $33 \mathrm{~km}$ east of the Manitoba-Ontario border late in the 1940s, is another creditable and supporting record.

A report of courting peregrines near Cape Merry as late as 1957, six reports of summer residents (one of which suggests nesting) and three other sources suggest that there is at least presumptive evidence that peregrines nested naturally in suitable locations in Manitoba in the historic period.

One reason peregrine eyries were not recorded more frequently in Manitoba may be the lack of suitable nesting habitat in southern Manitoba where the vast majority of bird observations are made. Also, in the recent past (after 1950), the Peregrine Falcon populations crashed because of pesticides (DDT in particular) and, therefore, one would not expect to find many, if any, peregrines in Manitoba from 1960 to the mid-1980s.

The available evidence indicates that historically, the Peregrine Falcon should be regarded as a rare but indigenous nesting species in Manitoba.

\section{Acknowledgements}

Appreciation is expressed to Herbert W.R. Copland who provided access to A.G. Lawrence's "Chickadee Notes," and to all authors and observers who submitted their records.

1. BECHARD, M.J. 1981. Historic nest records of the Peregrine Falcon in southern Saskatchewan and southern Manitoba. Blue Jay 39:182-183.

2. DUNCAN, J.R. 1990. Manitoba Peregrine Falcon survey. Unpubl. Rep., Manitoba Department of Natural Resources, Winnipeg. 5 pp. + appendices.

3. GARDNER, K.A. 1981. Birds of Oak Hammock Marsh Wildlife Management Area. Manitoba Department of Natural Resources, Winnipeg. 172 pp.

4. GODFREY, W.E. 1966. The birds of Canada. National Museum of Canada Bulletin No. 203, Biological Series No. 73, Ottawa. 428 pp.

5. HOCHBAUM, P.W. 1971. The Delta Marsh. Department of Mines, Resources and Environmental Management, Winnipeg. 52 pp.

6. HOUSTON, C.S. and M.J. BECHARD. 1987. Early Manitoba oologists. Blue Jay 45:85-96.

7. JEHL, J.R., JR. and B.A. SMITH. 1970. Birds of the Churchill region, Manitoba. Special Publication Number 1, Manitoba Museum of Man and Nature, Winnipeg. 87 pp.

8. LAWRENCE, A.G. 1921-55. "Chickadee Notes" [weekly column], Winnipeg Free Press.

9. MANNING, T.H. 1952. Birds of the west James Bay and southern Hudson Bay coasts. National Museum of Canada Bulletin No. 125, Biological Series No. 43, Ottawa. 114 pp.

10. SHORTT, T.M. and S. WALLER. 1937. The birds of the Lake St. Martin region. No. 10. Contributions of the Royal Ontario Museum of Zoology. 51 pp.

11. TAVERNER, P.A. and G.M. SUTTON. 1934. The birds of Churchill, Manitoba. Vol XXIII, Carnegie Museum. 83 pp.

12. TAYLOR, $P$. 1983. Wings along the Winnipeg. The birds of Pinawa-Lac du Bonnet region, Manitoba. Manitoba Naturalists Society Eco Series No. 2, Winnipeg. 216 pp.

13. THOMPSON, E.E. 1891. The birds of Manitoba. Smithsonian Institution, National Museum, Washington. 643 pp. 